\title{
Feeding Ecology and Establishment of the Naturally-Colonized Freshwater Cichlid, Sarotherodon galilaeus (Pisces: Actinopterigii: Perciformes) from a Man-Made Lake, South-Benin, West Africa
}

\author{
Houehanou M. A. G. Gbaguidi1 ${ }^{1}$ Alphonse Adite ${ }^{*}$, Edmond Sossoukpe ${ }^{2}$ \\ ${ }^{1}$ Laboratoire d'Ecologie et de Management des Ecosystèmes Aquatiques (LEMEA), Département de Zoologie, \\ Faculté des Sciences et Techniques, Université d'Abomey-Calavi, Cotonou, Bénin \\ ${ }^{2}$ Unité de Recherches sur les Zones Humides, Département de Zoologie, Faculté des Sciences et Techniques, \\ Université d'Abomey-Calavi, Cotonou, Bénin \\ Email: *alphonseadite@gmail.com
}

Received 12 April 2016; accepted 10 June 2016; published 13 June 2016

Copyright (C) 2016 by authors and Scientific Research Publishing Inc.

This work is licensed under the Creative Commons Attribution International License (CC BY). http://creativecommons.org/licenses/by/4.0/

\section{(c) (i) Open Access}

\begin{abstract}
The freshwater cichlid, Sarotherodon galilaeus (Linné, 1758) is an economically and commercially important fisheries species that has naturally colonized and dominated a sand-dragged man-made freshwater lake of Ahozon (South-Benin) where the species made about 85.21\% of the fish community. We investigated the feeding ecology of $S$. galilaeus in order to evaluate resource exploitation and the establishment of this species in Lake Ahozon. During wet, flood and dry seasons, 1189 individuals of $S$. galilaeus have been monthly sampled in the open water and in the aquatic vegetation habitats. The study showed that $S$. galilaeus consumed about seventy (70) food items dominated by algae (52.88\%) composed of 28 families and 52 genera from blue-green algae, green algae, desmids, and diatoms, sand particles $(23.95 \%)$, detritus $(12.27 \%)$ and protozoans $(7.68 \%)$. Minor preys were rotifers, copepods, cladodera, crustacea and insect parts. Foods items with

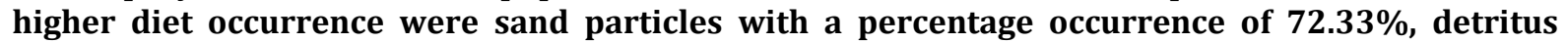
(69.47\%), and some algae such as Scenedesmus (58.96\%), Closterium (55.68\%), and Microcystis $(51.30 \%)$. Significant $(P \leq 0.05)$ ontogenetic variations of empty stomachs were recorded. $S$. galilaeus exhibited a wide diet breadth (DB) ranging between 5.55 and 7.29 that tended to increase with fish sizes. Diet overlaps $\left(\emptyset_{j k}\right)$ varied from 0.77 to 0.97 , indicating high diet similarities between different life stage categories. The slope $b=0.560$ obtained from Log (body weight)-Log (gut length) linear regression, and the mean ratio of GL/SL $=6.72 \pm 2.23$ support our findings that $S$. galilaeus exhibited detritivorous, herbivorous and omnivorous food habits. The broad spectrum

${ }^{*}$ Corresponding author.
\end{abstract}


of food resources consumed/utilized and the high diet breadth recorded leading to allometric growth, the active breeding and the high propagation of the species, were some indicators of the successful establishment of $S$. galilaeus in the man-made lake of Ahozon. Sustainable fisheries/ aquaculture exploitation of $S$. galilaeus and successful valorization of the man-made lake of Ahozon require an integrated management of the lake including the prevention of domestic waste dumpings, the protection of the foraging and spawning grounds, the fertilization of the lake, the introduction of predators to control the population of S. galilaeus, the protection of lake margin to avoid erosion, a planned harvest of the fish stock and a periodic ecological monitoring of Lake Ahozon.

\title{
Keywords
}

\author{
Algae, Artificial Lake, Diet Breadth, Diet Similarities, Ecomorphology, Establishment, Fisheries, \\ Foraging Grounds, Tilapine Species
}

\section{Introduction}

The freshwater cichlid, Sarotherodon galilaeus (Linné, 1758) is an economically and commercially important fish resource occurring in some natural freshwater bodies of Benin, such as Lakes Toho-Todougba, Dati, Ahouangan, the man-made lake from a sugar industry (SUCOBE), rivers such as Sô, Oueme, Niger and floodplains [1] [2]. In particular, S. galilaeus occurred abundantly in Lake Toho-Todougba (South-Benin) where the species made $73 \%$ of the total biomass [2]. In addition, in Southern Benin, S. galilaeus has naturally colonized and dominated a sand-dragged man-made freshwater lake of Ahozon Village (Ouidah City, County of Pahou) where the species reproduce actively, made about $85.21 \%$ of the fish community, and hence, appears to be well-established in this artificial lake [3] [4].

However, despite the high abundance of S. galilaeus in Lake Ahozon, and its economic and commercial importance, information on the ecology and biology of the species is scant. In particular, nothing is known about the feeding ecology of this tilapine cichlid in this abandoned and neglected artificial lake originated from a progressive accumulation of running water in an extensive hole created by sand-dragging activities. Knowledge on foods exploitation/utilization and feeding habits of fishes is crucial for a sound fisheries management and the development of aquaculture industries [5]-[9]. Indeed, foods are energy source of the various biological functions of fishes, and consistently affect fecundity, reproduction periodicity, recruitment, growth and condition factors of the species in its habitat [10] [11]. Furthermore, feeding ecology is important not only to understand the dynamic and the structure of the population, but also to evaluate the establishment of S. galilaeus in this special habitat, the sand-dragged man-made lake of Ahozon [12] [13].

Also, seasonal variations in preys availability greatly affects diet composition and the feeding patterns of the species [14] [15]. Since Lake Ahozon depends solely on running waters, the intensity of rainfall and seasonal hydrological regimes should affect the availability of marginal and open water habitats, and hence, preys availabilities [16] [17]. Diet breadth is an important feature in feeding ecology and measure the degree of trophic plasticity in fishes, that is, the capability of a fish to colonize many different habitats [18]. In trophic ecology, ontogenetic diet shifts depict the size-related patterns of feeding [19] [20]. In general the preys ingested vary according to fish development stages namely larva, juvenile, sub-adult and adult [21]. In fishes, the ecomorphological trends and reference ratios such as those from gut length could aid to predict or to confirm the food and feeding habits of a species [22]. Evaluating the prominence and establishment of S. galilaeus in the man-made lake of Ahozon requires extensive qualitative and quantitative knowledge on the exploitation and utilization of the food resources considered as energy sources for species survival, growth and active spawning.

The present research was carried out to investigate the feeding ecology of the freshwater cichlid, S. galilaeus, in order to evaluate its establishment in the sand-dragged artificial lake of Ahozon, and to contribute to the fisheries and aquacultural management of this special habitat. Specifically, the study aims to investigate on 1) diet composition and seasonal dietary variations of S. galilaeus in Lake Ahozon, 2) diet breadth (DB) variations, 3) diet overlap $\left(\varnothing_{j k}\right)$ between different size classes, and ontogenetic diet shifts, 4) ecomorphological correlates and food habits and 5) implications for fisheries, aquaculture development, species conservation and the overall es- 
tablishment of S. galilaeus in the man-made lake of Ahozon.

\section{Material and Methods}

\subsection{Study Region}

The man-made lake of Ahozon is located in Ouidah city (South-Benin), and lies between two water bodies, Toho-Todougba $\left(15 \mathrm{~km}^{2}\right)$, a freshwater lake, and the coastal lagoon $\left(60 \mathrm{~km}^{2}\right)$, a brackish water, both about $5 \mathrm{~km}$ apart from Lake Ahozon $\left(06^{\circ} 22^{\prime} 52^{\prime \prime} \mathrm{N}\right.$; $\left.002^{\circ} 10^{\prime} 34^{\prime \prime} \mathrm{E}\right)$. The artificial lake of Ahozon is a relatively small water bodies extending on about $0.165845 \mathrm{~km}^{2}$ (Figure 1) and originated from the accumulation of running waters in a hole created by sand-dragging activities. In general, after the exploitation of the sand, these artificial and unmanaged lakes are neglected and abandoned by the land owners.

The study region comprises some sandy soils, red ferric soils and a vast swampy soil located at the coastal zone and extended from Cotonou City (South-Benin) to Ouidah. The Southern Benin experiences a major wet season from April to July with a peak usually recorded in June, a minor wet season from mid-September to October, and two (2) dry seasons, a major one from December to March and the minor one from mid-August to mid-September [9]. Ambient temperatures varied between $25^{\circ} \mathrm{C}$ and $33.6^{\circ} \mathrm{C}$ and monthly evaporation ranged between 59.2 - $145 \mathrm{~mm}$ [23]. Annual mean rainfall was about $1307.3 \mathrm{~mm}$.

According to Gbaduidi et al. [4], Lake Ahozon showed depths varying between 16.2 and $240 \mathrm{~cm}$ (mean: $80.19 \mathrm{~cm}$ ) and transparencies between 16.2 and $60.5 \mathrm{~cm}$ (mean: $36.63 \mathrm{~cm}$ ). Water temperatures ranged between $28.2^{\circ} \mathrm{C}$ and $38.7^{\circ} \mathrm{C}$ (mean: $33.25^{\circ} \mathrm{C}$ ), $\mathrm{pH}$ between 6.7 and 9.7 (mean: 7.51). The dissolved oxygen concentrations ranged between 0.73 and $11.8 \mathrm{mg} / \mathrm{l}$ (mean: $5.43 \mathrm{mg} / \mathrm{l}$ ), the percentage of dissolved oxygen saturation between 10.5 and 208.8\% (mean: 82.9\%) and conductivity between 50 and $560 \mu / \mathrm{cm}$ (mean: $240 \mu / \mathrm{cm}$ ).

Dominant phytoplankton genera in Lake Ahozon were Navicula, Peridinium, Scennedesmus, Pinnularia,

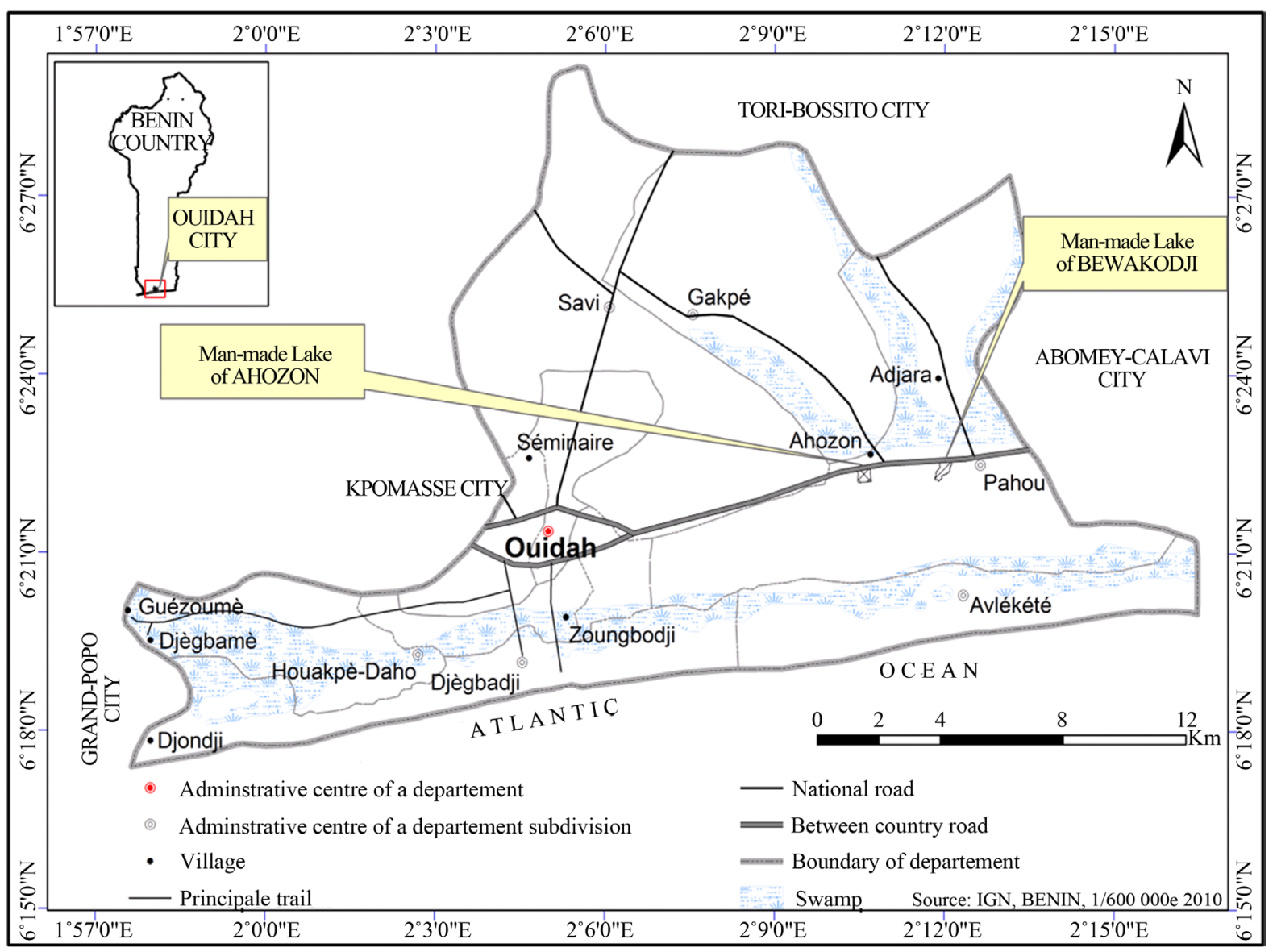

(a) 


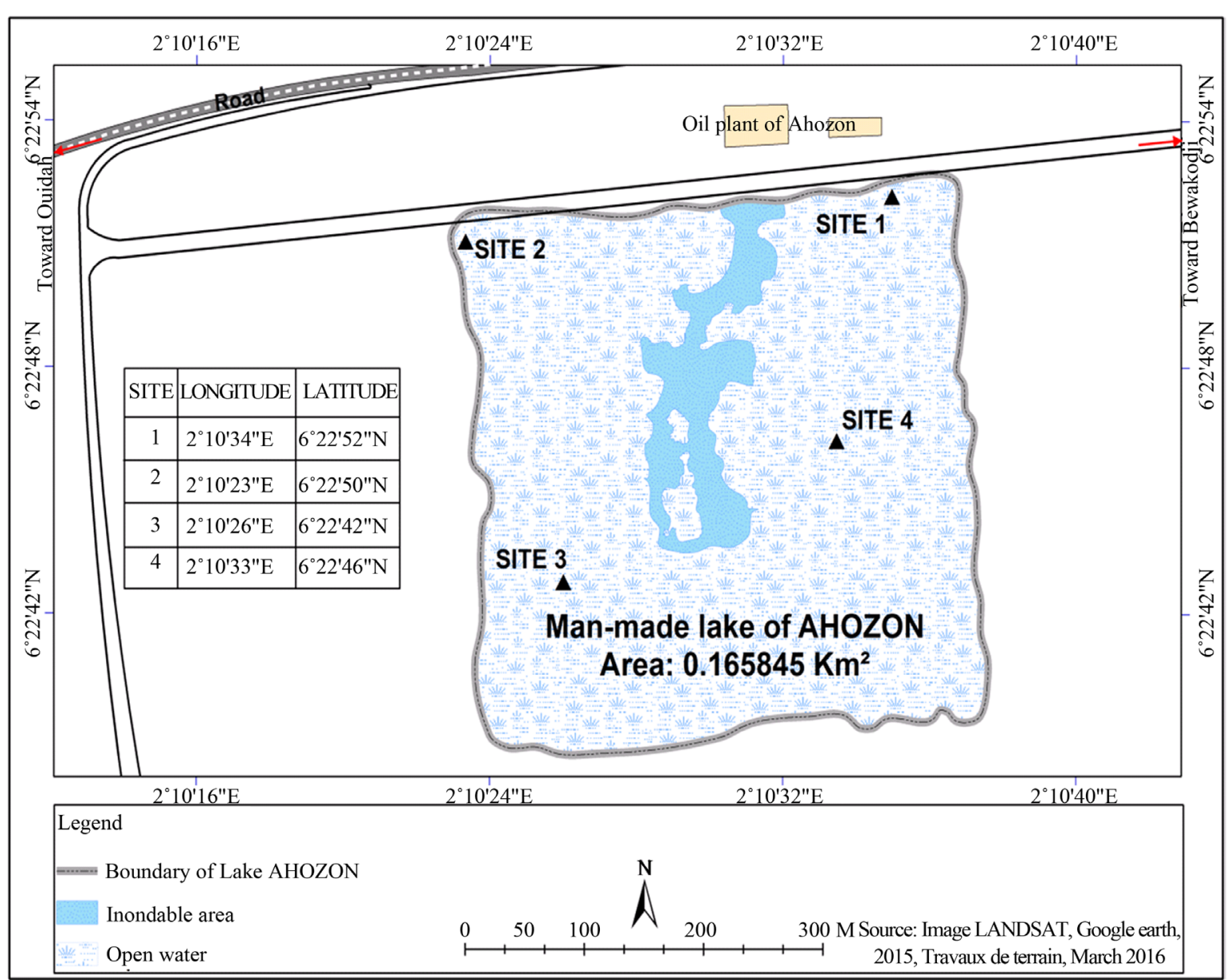

(b)

Figure 1. Map showing: (a) Ouidah City in South-Benin and the study location, the man-made lake of Ahozon, and (b) the sampling sites: Site 1 and Site 2 = Aquatic vegetation habitats; Site 3 and Site 4 = Open water habitats.

Spirogyra, Cosmarium, Melosira, Synechocystis, Microcystis, Oscillatoria, Euglena, Phacus, Surirella and Lychmophora and zooplanktons were dominated by Trichocerca, Keratella, Brachionus and copepods. Benthic macro invertebrates recorded were chironomid larvae and a Gasteropod mollusk, Melanoïde tubercularis. Aquatic vegetation mainly comprised Cyperus crassipes, Cyperus rotundus, Fuirena umbellata, Andropogon gayanus, Ludwigia perennis, Emilia praetermissa, Eleocharis complanata, Enydra fluctuans et Mariscus ligularis. The ichtyofauna of Lake Ahozon comprised three tilapine cichlids, Sarotherodon galilaeus, the dominant species, Oreochromis niloticus and Tilapia guineensis, a claroteid, Chrysichthys nigrodigitatus, the African bonytongue, Heterotis niloticus (Osteoglossidae), and the African catfish, Clarias gariepinus (Clariidae) (Gbaguidi et al., in press). Subsistence multi species fisheries sporadically occurred in the man-made lake of Ahozon and were practiced by a couple of migrant fishermen. In term of agricultural exploitation, some plantations such as those of Elaeis guineensis (palm tree) and Coco nucifera (coconut tree) occurred around Lake Ahozon [2]. In addition, the water of Lake Ahozon is utilized for sporadic subsistence and commercial agriculture involving beans, carrots lettuce, tomatoes, cucumbers and salads.

\subsection{Sampling Sites}

Four sampling sites were selected for the study, two (2) sites in the "open water" habitat and two (2) sites in the "aquatic vegetation" habitat (Figure 1). The "open water" habitat exhibited a relatively high depth and high water velocity, but exempt of vegetation whereas the "aquatic vegetation", the edge of the lake, is shallow and characterized by a low water velocity and relatively dense vegetation. 


\subsection{Aspects of Systematic and Biology}

Taxonomically, Sarotherodon galilaeus is a tilapine cichlid belonging to the genus Sarotherodon, family Cichlidae, Percoidei Sub-order, Perciformes Order and Acanthopterygii Super Order. Synonimies are Sparus galilaells, Chromis galilaeus, Tilapia galilaea. The species exhibited a grew silvery color with juveniles showing black vertical lines on the sides. According to Leveque et al. [24], head length is $32.5 \%-39.0 \%$ the standard length (SL), body height is $43.0 \%-56.5 \%$ SL and pectoral length is $36.0 \%-50.0 \%$ SL. Meristic counts showed 29 - 32 scales on the lateral line, 4 - 8 lines of teeths on the jaws, and the lower pharyngeal bone possesses numerous small teeth. S. galilaeus exhibited diverse reproductive behaviors such as mouth brooding, nest construction, nest guarding and parental care. In Lake Ahozon, the species is characterized by an early reproduction and sizes at sexual maturation (L50) were $131 \mathrm{~mm}$-TL and $106 \mathrm{~mm}$-TL, respectively for males and females. In the International Institute of Tropical Agriculture (IITA) Lake of Ibadan, Fagade [9] [10] reported the species as foraging mainly on algae.

\subsection{Fish Sample Collection}

Specimens of S. galilaeus were sampled twice a month from August 2014 to July 2015 in the "aquatic vegetation habitat" and in the "open water" using various fishing gears such as cast net $(9.80 \mathrm{~m}$-diameter, $4.90 \mathrm{~m}$ height, $40 \mathrm{~mm}$-mesh), seine (4.15 m-length $\times 1.77 \mathrm{~m}$-width, $3 \mathrm{~mm}$-mesh), hooks (90 m-length) and experimental gill net $(40 \mathrm{~m} \times 1.05 \mathrm{~m}, 40 \mathrm{~mm}$ mesh). Seinings were done in the marginal aquatic vegetation by setting the seine stationary, and kicking the vegetation to drive the fish in to the net [2]. Cast nets, gill nets and hooks were used in the "open water". After collection, fish samples were preserved in 10\% formalin and then transported to the "Laboratory of Ecology and Management of Aquatic Ecosystems". In the lab, the fish samples were removed from the formalin and preserved in 70\% ethanol [4].

\subsection{Laboratory Procedure and Stomach Content Analysis}

In the laborabory, the ethanol preserved-fishes were identified using references such as Leveque et al., [24], Van Thielen et al. [1], and Lowe McConnell [25] [26]. S. galilaeus were then measured with a graduated measuring board for total length (TL) and standard length (SL) to the nearest $0.1 \mathrm{~mm}$ with an ichtyometer, and weighed to the nearest $0.1 \mathrm{~g}$ with an electronic balance (Philips).

Each specimen of $S$. galilaeus was then dissected, and the digestive canal was removed and its length was measured as the distance from the distal end to the anus [27]. The gut was then opened and all the stomach contents were removed and spread on a transparent container for examination first under a binocular (model: Pierron) to identify large preys. In case of high level of digestion, fragments or parts of items were identified and inferences were made on the food resources (algae, microcrocrustacea, insects etc.) consumed. Sometimes, water was added to facilitate separation of small items. To identify the phytoplankton, a sub-sample of known volume of the stomach contents was taken and the total gross volume was estimated by water displacement using an appropriately sized graduated cylinder. Before measuring the total gross volume, the food was blotted on a paper towel to remove excess moisture. The volumes of the sub-samples were estimated by spreading the food materials on a glass slide then visually estimating the collective volume by comparison with a sample of known volume $(<0.002 \mathrm{ml})$ [13]. The sub-sample is then examined under a photonic microscope. Preys were identified to the lowest possible taxonomic level using the identification key of Needham [28] for phytoplankton, zooplankton and aquatic invertebrates. After identification, the volumetric percentage of each prey was estimated for the sub-sample and then for the total gross stomach content [9].

\subsection{Data Analysis}

Overall, 1189 stomachs of $S$. galilaeus were dissected. For each individual, the estimated volume of each prey item was recorded on Excel software spreadsheet and the volumetric proportion of each prey was computed following the formula:

$$
p_{i}=\sum_{i=1}^{n} v i / V t
$$

where $\boldsymbol{p}_{\boldsymbol{i}}$ is the volumetric proportion of food item $\boldsymbol{i}$ in the diet, $\boldsymbol{n}$ is the number of stomachs, $\boldsymbol{v} \boldsymbol{i}$ is the volume of 
the food item $i$ in a single stomach, $V \boldsymbol{t}$ is the total volume of food ingested by $n$ stomachs. Seasonal (wet, flood, dry) variations in volumetric proportions were depicted with analysis of variances (ANOVA) using SPSS [29]. Also, volumetric proportions of each food item ingested were computed for different sizes classes of $S$. galilaeus to explore ontogenetic diet shifts. Niche breadth was calculated following Simpson's diet breadth formula [30]:

$$
\text { Diet breadth }(\mathrm{DB})=1 / \sum_{i=1}^{n} p_{i}^{2}
$$

where $\boldsymbol{p}_{\boldsymbol{i}}$ is the proportion of food item $\boldsymbol{i}$ in the diet, and $\boldsymbol{n}$ is the total number of food items in the diet. DB ranges from $\mathbf{1}$, when only one resource is used, to $\boldsymbol{n}$, when all resources are consumed in equal proportions. The values of computed indices were submitted to one-way analysis of variances (ANOVA) using SPSS software computer program [29]. Diet overlap was calculated using Pianka’s overlap index $\left(\varnothing_{j k}\right)$ [31]:

$$
\varnothing_{j k}=\frac{\sum_{i=1}^{n} P_{i j} P_{i k}}{\left(\sum_{i=1}^{n} P_{i j}^{2} \times \sum_{i=1}^{n} P_{i k}^{2}\right)^{1 / 2}}
$$

where $\varnothing_{j \boldsymbol{k}}$ is dietary overlap between species $\boldsymbol{j}$ and species $\boldsymbol{k}, \boldsymbol{p}_{i j}$ is the proportion of resource $\boldsymbol{i}$ used by species $\boldsymbol{j}$, $\boldsymbol{p}_{\boldsymbol{i k}}$ is the proportion of resource $\boldsymbol{i}$ used by species $\boldsymbol{k}$, and $\boldsymbol{n}$ is the number of resource categories utilized.

To explore the ecomorphological correlates, the linear regression analysis between body weight (W) and gut length (GL) were examined as well as the ratio of gut length and standard length (GL/SL).

\section{Results}

\subsection{Diet Composition}

Table 1 shows the matrix of food resources ingested by S. galilaeus in the man-made lake of Ahozon and their respective volumetric proportions. In Lake Ahozon, S. galilaeus consumed about seventy (70) food items from benthic and pelagic habitats. Dominant diet items were algae accounting for 52.88\%, sand particles (23.95\%), detritus (12.27\%) and protozoans (7.68\%) (Figure 2). Aggregated algae were composed of 28 families and 52 genera including blue-green algae (24.48\%), green algae (11.77\%), desmids (8.29\%) and diatoms (8.35\%).

Blue-green algae comprised eighteen (18) genera, with three (3) Chroococcaceae Mycrocystis (12.25\%), Synechocystis (3.87\%), Coelosphaerium (3.15\%) and Nostoc (1.92\%), a Nostococacea, the most abundant items. The remaining 14 blue-green algae individually, made less than $0.84 \%$. Green algae comprised nine (9) genera with Scenedesmus (6.97\%), a Scenedesmaceae and Botryoccocus (2.99\%) a Dictyosphaeriacae the most abundant green algae items. The remaining seven (7) green algae, Ankistrodesmus, Crucigenia, Coelastrum, Tetraspora, Ulothrix, Binuclearia, Ophiocytium individually made less than $0.70 \%$. Thirteen (13) genera of desmids, Colacium, Closterium, Euastrum, Staurastrum, Gonatozygon, Tetmemorus, Cosmarium, Euglena, Phacus, Micractinium, Selenastrum, Peridinium and Cymatopleura were recorded in the diet of S. galilaeus with Closterium (5.97\%) a Desmidiaceae and Phacus (1.16\%), an Euglenaceae, the most abundant. Twelve (12) genera of diatoms, Chaetoceros, Fragilaria, Stephanodiscus, Anomoeneis, Navicula, Pinnularia, Gomphonema, Cymbella, Melosira, Asterionella, Nitzschia and Cyclotella were recorded in the diet of S. galilaeus with 2 Naviculaceae, Navicula (2.95\%), Pinnularia (2.12\%) and a Coscinodisceae, Melosira (2.84\%), the most abundant diatoms.

In general, among algae, Chroococcaceae was the most speciose and dominant family constituated of nine (9) genera, Microcystis, Synechocystis, Coelosphaerium, Gomphosphaeria, Synechococcus, Polycystis, Chroococus, Merismopedia, Tetrapedia making about $20.34 \%$ of the diet. Other speciose algae families were Desmidiaceae with 6 genera, Closterium, Euastrum, Staurastrum, Gonatozygon, Tetmemorus, Cosmarium, Naviculaceae with 5 genera, Anomoeneis, Navicula, Pinnularia, Gomphonema, Cymbella, Scenedesmaceae with 3 genera, Scenedesmus, Crucigenia and Coelastrum. The remaining 24 algae families comprised no more than 1 or 2 genera.

Eleven (11) algae, Nostoc (Nostocaceae), Botryoccocus (Dictyosphaeriacae), Scenedesmus (Scenedesmaceae), Closterium (Desmidiaceae), Phacus (Euglenaceae), Melosira (Coscinodisceae), three Chroococcaceae, Microcystis, Synechocystis, Coelosphaerium, 2 Naviculaceae, Navicula, Pinnularia were relatively more abundant and made together $46.09 \%$. The 41 remaining algae made $53.91 \%$ and none of them had a volumetric proportion more than $0.86 \%$. 
Table 1. Volumetric and occurrence percentages (\%) of food resources consumed by Sarotherodon galilaeus $(\mathrm{N}=1189)$ from the artificial lake of Ahozon (South-Benin).

\begin{tabular}{|c|c|c|c|c|c|}
\hline Prey categories & Prey families & Genera & $\begin{array}{c}\text { Volumetric } \\
\text { percentage (\%) }\end{array}$ & $\begin{array}{c}\text { Occurrence } \\
\text { (number) }\end{array}$ & $\begin{array}{c}\text { Percentage } \\
\text { occurrence (\%) }\end{array}$ \\
\hline \multirow[t]{18}{*}{ Bleue-green algae } & Chroococcaceae & Coelosphaerium & 3.15 & 196 & 16.48 \\
\hline & Chroococcaceae & Mycrocystis & 12.25 & 610 & 51.30 \\
\hline & Chroococcaceae & Gomphosphaeria & 0.01 & 4 & 0.34 \\
\hline & Chroococcaceae & Synechocystis & 3.87 & 262 & 22.04 \\
\hline & Chroococcaceae & Synechococcus & 0.30 & 24 & 2.02 \\
\hline & Chroococcaceae & Polycystis & 0.57 & 24 & 2.02 \\
\hline & Chroococcaceae & Chroococus & 0.13 & 15 & 1.26 \\
\hline & Chroococcaceae & Merismopedia & 0.06 & 8 & 0.67 \\
\hline & Chroococcaceae & Tetrapedia & 0.003 & 1 & 0.08 \\
\hline & Microchaetaceae & Microchaete & 0.005 & 1 & 0.08 \\
\hline & Nostocaceae & Anabaena & 0.84 & 112 & 9.42 \\
\hline & Nostocaceae & Nostoc & 1.92 & 281 & 23.63 \\
\hline & Oscillatoriaceae & Oscillatoria & 0.01 & 13 & 1.09 \\
\hline & Oscillatoriaceae & Spirulina & 0.37 & 53 & 4.46 \\
\hline & Palmellaceae & Sphaerocystis & 0.13 & 5 & 0.42 \\
\hline & Pleurococcacae & Protococus & 0.14 & 5 & 0.42 \\
\hline & Rivulariaceae & Calothrix & 0.10 & 54 & 4.54 \\
\hline & Rivulariaceae & Rivularia & 0.62 & 68 & 5.72 \\
\hline \multirow[t]{9}{*}{ Green algae } & Dictyosphaeriacae & Botryoccocus & 2.99 & 177 & 14.89 \\
\hline & Oocystaceae & Ankistrodesmus & 0.66 & 95 & 7.99 \\
\hline & Scenedesmaceae & Scenedesmus & 6.97 & 701 & 58.96 \\
\hline & Scenedesmaceae & Crucigenia & 0.60 & 67 & 5.63 \\
\hline & Scenedesmaceae & Coelastrum & 0.04 & 13 & 1.09 \\
\hline & Tetrasporaceae & Tetraspora & 0.44 & 34 & 2.86 \\
\hline & Ulothricaceae & Ulothrix & 0.01 & 3 & 0.25 \\
\hline & Ulothricaceae & Binuclearia & 0.04 & 8 & 0.67 \\
\hline & Xanthophyceae & Ophiocytium & 0.02 & 1 & 0.08 \\
\hline \multirow[t]{10}{*}{ Desmids } & Colaciaceae & Colacium & 0.02 & 6 & 0.50 \\
\hline & Desmidiaceae & Closterium & 5.87 & 662 & 55.68 \\
\hline & Desmidiaceae & Euastrum & 0.02 & 16 & 1.35 \\
\hline & Desmidiaceae & Staurastrum & 0.02 & 10 & 0.84 \\
\hline & Desmidiaceae & Gonatozygon & 0.03 & 6 & 0.50 \\
\hline & Desmidiaceae & Tetmemorus & 0.01 & 2 & 0.17 \\
\hline & Desmidiaceae & Cosmarium & 0.005 & 5 & 0.42 \\
\hline & Euglenaceae & Euglena & 0.03 & 2 & 0.17 \\
\hline & Euglenaceae & Phacus & 1.16 & 98 & 8.24 \\
\hline & Micractiniaceae & Micractinium & 0.13 & 18 & 1.51 \\
\hline
\end{tabular}




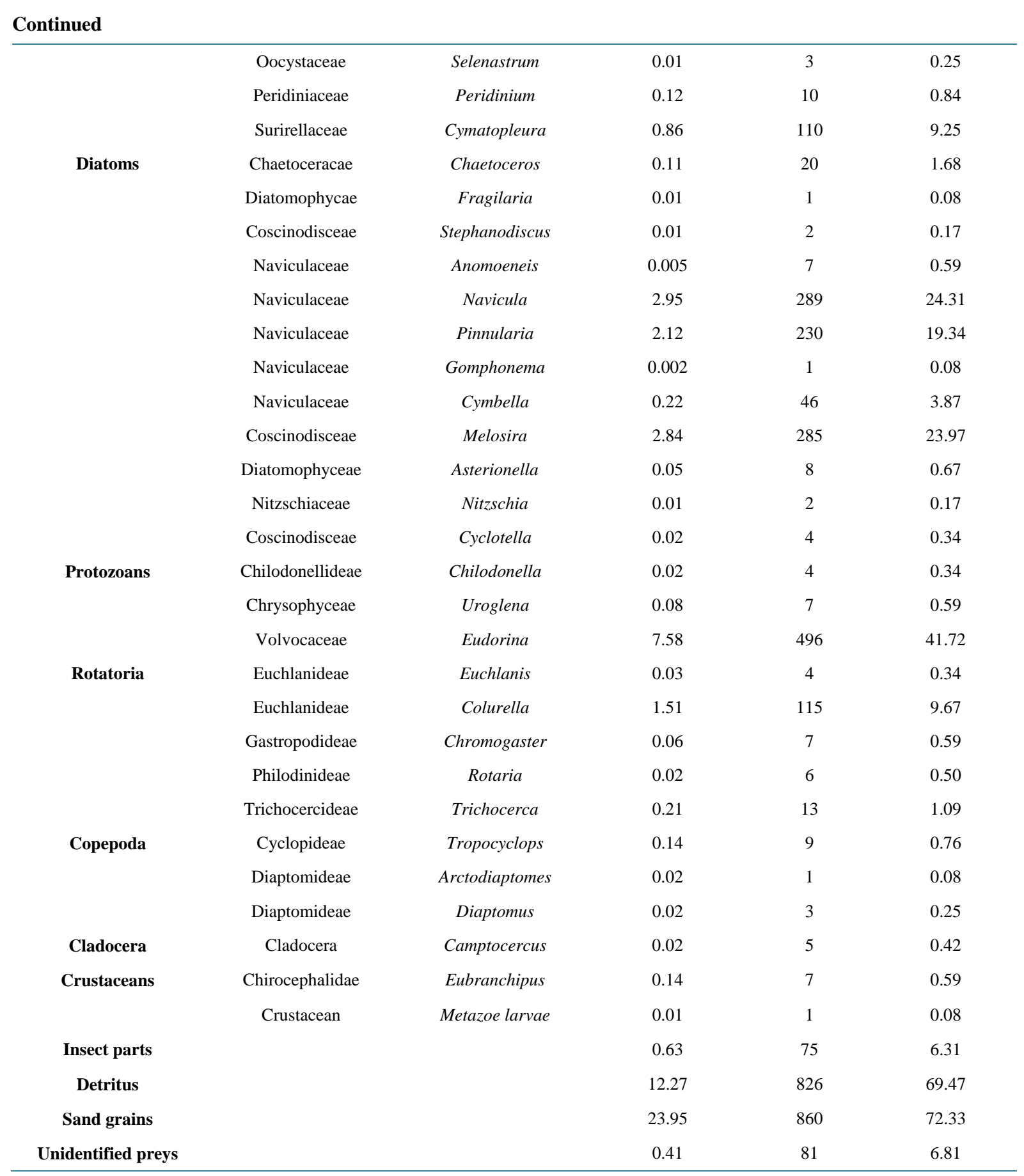

Protozoans were mostly Eudorina (7.58\%), a Volvocaceae, the dominant genus, Uroglena (Chrysophyceae) and Chilodonella (Chilodonellideae). Minor preys (3.22\%) recorded included Rotifers (Euchlanis, Colurella, Chromogaster, Rotaria, Trichocerca), microcrustacea composed of Copepods (Diaptomus, Arctodiaptomes, Tropocyclops), Cladocerans (Camptocercus), and other uncommon diet items such as Crustaceans (Eubranchipus, metazoe larvae), and insects parts.

\subsection{Occurrence}

In S. galilaeus, the lowest diet percentage occurrence (0.08\%) was recorded for Tetrapedia (Chroococcaceae), 


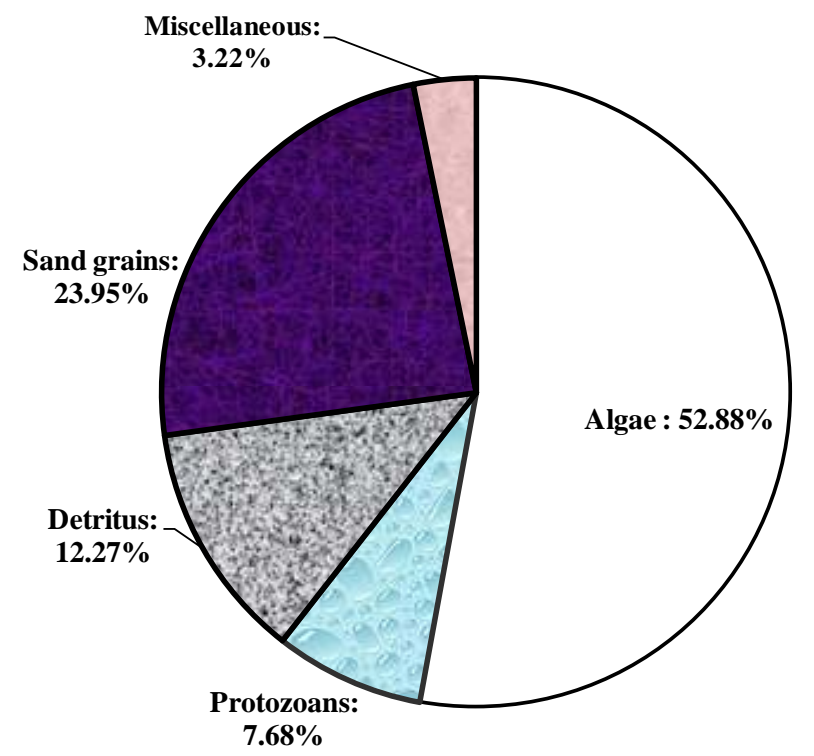

Figure 2. Volumetric percentage (\%) of the foods resources ingested by Sarotherodon galilaeus ( $n=1189$ ) from the artificial lake of Ahozon (South-Benin).

Microchaete (Microchaetaceae), Ophiocytium (Xanthophyceae), Fragilaria (Diatomophycae), Arctodiaptomes (Naviculaceae), Gomphonema (Diaptomideae) and Crustacean (Table 1). The highest occurrence recorded was $72.33 \%$ and corresponded to 860 individuals of S. galilaeus that have ingested sand particles, which alone dominated the stomach content with a volumetric proportion of $23.95 \%$. In addition, of the 70 foods items recorded, the ten (10) first preys with relatively higher occurrence were sand grains occurring in 860 stomachs (72.23\%), detritus occurring in 826 (69.47\%), Scenedesmus (Scenedesmaceae) found in 701 (58.96\%) stomachs, Closterium (Desmidiaceae) found in 662 (55.68\%) stomachs, Microcystis (Chroococcaceae) occurring in 610 (51.3\%) stomachs, Eudorina (Volvocaceae) occurring in 496 (41.72\%) stomach, Navicula (Naviculaceae) recorded in 289 (24.31\%) stomachs, Melosira (Coscinodisceae) recorded in 285 (23.97\%) stomachs, Nostoc (Nostocaceae) occurring in 281 (23.63\%) stomachs and Synechocystis (Chroococcaceae) occurring in 262 (22.04\%) stomachs.

\subsection{Empty Stomachs}

In Lake Ahozon, empty stomachs significantly $(P \leq 0.05)$ varied with the life stages categories (size classes) of S. galilaeus and ranged between $0.40 \%$ recorded for adults subpopulation and $83.33 \%$ recorded for small juveniles (Table 2). Indeed, one-way analysis on the percentage of empty stomachs gave $F_{3,11}=3.905$ with $p$-value $=0.05$, thus showing ontogenetic variations of empty stomachs. Overall, empty stomachs in small juveniles were higher and ranged between $28.57 \%$ - 83.33\%. Those of large juveniles and subadults ranged between $11.11 \%$ - $45.59 \%$ and $2.78 \%$ - 22.73\%, respectively. Adults exhibited lower empty stomachs varying between $0.40 \%$ and $11.76 \%$. In contrast, the incidences of empty stomachs were not associated with seasons. Indeed, one-way ANOVA on the percentage of empty stomachs fail to show any significant $\left(F_{2,11}=0.339, p=0.721\right)$ seasonal variations.

\subsection{Diet Breadth}

In Lake Ahozon, S. galilaeus had a relatively high diet breadth $(\mathrm{DB}=6.01)$ indicating that this species consumed a relatively broad spectrum of food resources. Ontogenetically, one-way ANOVA showed significant ( $p$ $\leq 0.005$ ) variations among computed diet breadth for different life stage categories. Indeed, the computed $F$-value, along with degrees of freedom and $p$-value was $F_{2,15}=6.726, p=0.007$. In general, diet breadth tended to increase with fish sizes and ranged from $\mathrm{DB}=5.55$ for small juveniles ( $\mathrm{TL}<30 \mathrm{~mm})$ to $\mathrm{DB}=7.29(50 \mathrm{~mm} \leq$ $\mathrm{TL}<90 \mathrm{~mm}$ ) for subadults (Table 3). Inversely, one-way analysis of variance on diet breadth fails to show any significant $(P>0.05)$ seasonal variations. The computed $F$-value, along with degrees of freedom and $p$-value was $F_{2,11}=0.749, p=0.500$. Nevertheless, diet breadth was higher during the dry season $(\mathrm{DB}=6.36)$ compared 
Table 2. Percentages (\%) of empty stomachs recorded by life stage category of Sarotherodon galilaeus from the artificial lake of Ahozon (South-Benin) during wet, flood and dry season.

\begin{tabular}{ccccccc}
\hline & \multicolumn{2}{c}{ Wet } & \multicolumn{2}{c}{ Flood } & \multicolumn{2}{c}{ Dry } \\
\hline S. galilaeus life stages & $\begin{array}{c}\text { No. of } \\
\text { individuals }\end{array}$ & $\begin{array}{c}\text { Empty } \\
\text { stomachs (\%) }\end{array}$ & $\begin{array}{c}\mathrm{N}^{\circ} \text { of } \\
\text { individuals }\end{array}$ & $\begin{array}{c}\text { Empty } \\
\text { stomachs (\%) }\end{array}$ & $\begin{array}{c}\text { No. of } \\
\text { individuals }\end{array}$ & $\begin{array}{c}\text { Empty } \\
\text { stomachs (\%) }\end{array}$ \\
\hline Small juveniles & 21 & 28.57 & 6 & 83.33 & 16 & 43.75 \\
Large juveniles & 63 & 11.11 & 68 & 45.59 & 58 & 31.03 \\
Subadults & 88 & 22.73 & 26 & 2.78 & 60 & 11.67 \\
Adults & 306 & 11.76 & 250 & 0.40 & 227 & 10.13 \\
Total & $\mathbf{4 7 8}$ & $\mathbf{1 4 . 4 4}$ & $\mathbf{3 5 0}$ & $\mathbf{1 0 . 8 6}$ & $\mathbf{3 6 1}$ & $\mathbf{1 4 . 9 6}$ \\
\hline
\end{tabular}

Total number of individuals: 1189. Total number of empty stomachs $(\mathbf{1 6 1})$ : Wet $=\mathbf{6 9}$; Flood = 38; Dry = 54. Total percentage $(\%)$ of empty stomachs: $13.54 \%$.

Table 3. Diet breadth (DB) by season and life stage category of Sarotherodon galilaeus $(\mathrm{N}=1189)$ from the artificial lake of Ahozon (South-Benin).

\begin{tabular}{ccccc}
\hline Seasons & \multicolumn{3}{c}{ Life stage categories } \\
\hline & Small juveniles & Large juveniles & Subadults & Adults \\
\hline Wet & 6.18 & 6.23 & 6.50 & 5.64 \\
Flood & 3.57 & 6.13 & 6.81 & 5.03 \\
Dry & 4.44 & 6.79 & 7.13 & 6.23 \\
Total DB & $\mathbf{5 . 5 5}$ & $\mathbf{6 . 8 5}$ & $\mathbf{7 . 2 9}$ & $\mathbf{5 . 8 7}$ \\
Abundance & $\mathbf{4 3}$ & $\mathbf{1 8 9}$ & $\mathbf{1 7 4}$ & $\mathbf{7 8 3}$ \\
\hline
\end{tabular}

to those of wet and flood seasons (Table 3).

\subsection{Seasonal Variations of Diet}

Except detritus, most food items (sand particules, algae, protozoans, rotifers) consumed by S. galilaeus fail to show any significant $(p>0.05)$ seasonal variations. The calculated $F$ and $p$ values was $F_{2,11}=1.611, p=0.252$ for sand particles, $F_{2,11}=0.904, p=0.439$ for aggregated algae, $F_{2,11}=0.208, p=0.816$ for protozoans, and $F_{2,11}$ $=1.121, p=0.367$ for rotifers. Nevertheless, proportional consumption of sand particles was greater during the high-water season with a volumetric proportion reaching 31.69\% (Figure 3). Likewise, proportional consumption of algae and protozoans were greater during the dry season with volumetric proportions reaching $57.04 \%$ and $11.28 \%$, respectively. Also, the highest volumetric proportion of rotifers $(2.42 \%)$ was recorded during the wet season. In contract, the volumetric proportion of detritus showed significant $\left(F_{2,11}=4.302, p=0.049\right)$ seasonal variations with the highest proportional consumption (16.05\%) recorded during the dry season.

\subsection{Pianka's Diet Overlaps and Ontogenetic Diet Shifts}

In this study, diet overlaps $\left(\varnothing_{j k}\right)$ evaluate dietary similarity between subpopulations of different size classes or life stages. Overall, diet overlaps ranged from $\varnothing_{j k}=0.77$ for the pairing "small juveniles $\mathrm{X}$ adults" to $\varnothing_{j k}=0.97$ for the pairing "subadult X adults", and averaged $\varnothing_{j k}=0.87 \pm 0.08$, an indication of high diet similarities among different life stage categories (Table 4). In general, adjacent life stages or size classes tended to exhibit higher diet overlaps than distant pairings involving distant size classes categories. This trend indicated ontogenetic diet shifts, also shown by the increase in the proportional consumption of sand particles \& detritus with S. galilaeus size classes. The associated regression equation gave a positive slope $b=0.241$ along with a significant $(p \leq$ 0.01 ) correlation coefficient $r=0.99$. Also, the volumetric proportion of sand particles \& detritus ranged between $23.1 \%$ for small juveniles (TL $<30 \mathrm{~mm}$ ) to $37.04 \%$ for adults (TL $\geq 90 \mathrm{~mm}$ ) (Table 5). Though proportional consumptions of aggregated algae by different size classes were not significantly $(p>0.05)$ different, the 
Table 4. Matrix of diet overlaps $\left(\varnothing_{i k}\right)$ of Sarotherodon galilaeus $(\mathrm{N}=1189)$ by life stage category from the artificial lake of Ahozon (South-Benin).

\begin{tabular}{ccccc}
\hline S. galilaeus life stages & Small juveniles & Large juveniles & Subadults & Adults \\
\hline Small juveniles & 1 & 0.78 & 0.86 & 0.77 \\
Large juveniles & & 1 & 0.92 & 0.90 \\
Subadults & & 1 & 0.97 \\
Adults & & & 1 \\
\hline
\end{tabular}

Table 5. Volumetric percentages (\%) of food resources consumed by size classes (mm TL) of Sarotherodon galilaeus ( $\mathrm{N}=$ 1189) from the artificial lake of Ahozon (South-Benin). TL = Total length.

\begin{tabular}{|c|c|c|c|c|c|c|}
\hline Prey categories & Prey families & Genera & $\begin{array}{c}\text { Small juvenile } \\
(\mathrm{TL}<30)\end{array}$ & $\begin{array}{c}\text { Juveniles } \\
(30 \leq \mathrm{TL}<\mathbf{5 0})\end{array}$ & $\begin{array}{c}\text { Subadults } \\
(\mathbf{5 0} \leq \mathrm{TL}<\mathbf{9 0})\end{array}$ & $\begin{array}{c}\text { Adults } \\
(\mathrm{TL} \geq 90)\end{array}$ \\
\hline \multirow[t]{18}{*}{$\begin{array}{c}\text { Bleue-green } \\
\text { algae }\end{array}$} & Chroococcaceae & Coelosphaerium & - & 9.02 & 3.97 & 3.00 \\
\hline & Chroococcaceae & Microcystis & 1.73 & 1.40 & 10.33 & 12.60 \\
\hline & Chroococcaceae & Gomphosphaeria & - & 0.06 & - & 0.02 \\
\hline & Chroococcaceae & Synechocystis & 0.74 & 2.33 & 3.19 & 3.97 \\
\hline & Chroococcaceae & Synechococcus & 0.45 & 0.03 & 0.28 & 0.30 \\
\hline & Chroococcaceae & Polycystis & - & - & 0.52 & 0.58 \\
\hline & Chroococcaceae & Chroococus & - & - & 0.45 & 0.09 \\
\hline & Chroococсасеае & Merismopedia & 0.19 & 0.04 & 0.04 & 0.07 \\
\hline & Chroococcaceae & Tetrapedia & - & - & - & 0.004 \\
\hline & Microchaetaceae & Microchaete & - & - & - & 0.002 \\
\hline & Nostocaceae & Anabaena & - & 4.47 & 0.73 & 0.82 \\
\hline & Nostocaceae & Nostoc & 3.98 & 3.51 & 1.11 & 2.00 \\
\hline & Oscillatoriaceae & Oscillatoria & - & 0.12 & 0.06 & 0.002 \\
\hline & Oscillatoriaceae & Spirulina & 0.28 & 6.60 & 0.46 & 0.31 \\
\hline & Palmellaceae & Sphaerocystis & - & - & 0.36 & 0.11 \\
\hline & Pleurococcacae & Protococus & - & - & 0.02 & 0.16 \\
\hline & Rivulariaceae & Calothrix & 2.42 & 3.66 & 0.31 & 0.04 \\
\hline & Rivulariaceae & Rivularia & 1.45 & 2.56 & 0.47 & 0.62 \\
\hline \multirow[t]{9}{*}{ Green algae } & Dictyosphaeriacae & Botryoccocus & - & 7.16 & 2.56 & 3.01 \\
\hline & Oocystaceae & Ankistrodesmus & 1.06 & 0.10 & 0.38 & 0.70 \\
\hline & Scenedesmaceae & Scenedesmus & 13.47 & 3.39 & 6.76 & 7.03 \\
\hline & Scenedesmaceae & Crucigenia & - & 1.52 & 0.24 & 0.63 \\
\hline & Scenedesmaceae & Coelastrum & 0.41 & 0.13 & - & 0.04 \\
\hline & Tetrasporaceae & Tetraspora & - & 0.07 & 0.29 & 0.46 \\
\hline & Ulothricaceae & Ulothrix & - & - & - & 0.007 \\
\hline & Ulothricaceae & Binuclearia & 0.85 & - & 0.18 & 0.02 \\
\hline & Xanthophyceae & Ophiocytium & - & - & - & 0.02 \\
\hline \multirow[t]{2}{*}{ Desmids } & Colaciaceae & Colacium & 4.13 & - & - & 0.02 \\
\hline & Desmidiaceae & Closterium & 3.44 & 5.60 & 6.77 & 5.77 \\
\hline
\end{tabular}




\section{Continued}

\begin{tabular}{|c|c|c|c|c|c|c|}
\hline & Desmidiaceae & Euastrum & 0.84 & 1.49 & - & 0.008 \\
\hline & Desmidiaceae & Staurastrum & - & 0.28 & - & 0.02 \\
\hline & Desmidiaceae & Gonatozygon & - & - & - & 0.04 \\
\hline & Desmidiaceae & Tetmemorus & - & - & 0.04 & 0.009 \\
\hline & Desmidiaceae & Cosmarium & 0.32 & 0.01 & 0.01 & 0 \\
\hline & Euglenaceae & Euglena & - & - & - & 0.04 \\
\hline & Euglenaceae & Phacus & 0.97 & 0.06 & 1.18 & 1.17 \\
\hline & Micractiniaceae & Micractinium & 0.48 & - & 0.08 & 0.14 \\
\hline & Oocystaceae & Selenastrum & - & - & - & 0.01 \\
\hline & Peridiniaceae & Peridinium & - & 0.04 & 0.30 & 0.10 \\
\hline & Surirellaceae & Cymatopleura & 0.80 & 2.83 & 1.92 & 0.71 \\
\hline \multirow[t]{12}{*}{ Diatoms } & Chaetoceracae & Chaetoceros & 0.22 & 0.10 & 0.11 & 0.11 \\
\hline & Diatomophycae & Fragilaria & - & - & - & 0.01 \\
\hline & Coscinodisceae & Stephanodiscus & - & - & - & 0.02 \\
\hline & Naviculaceae & Anomoeneis & 0.45 & 0.10 & - & 0.004 \\
\hline & Naviculaceae & Navicula & 4.65 & 3.99 & 3.12 & 2.92 \\
\hline & Naviculaceae & Pinnularia & 6.84 & 0.44 & 2.23 & 2.12 \\
\hline & Naviculaceae & Gomphonema & - & - & - & 0.002 \\
\hline & Naviculaceae & Cymbella & 5.58 & 1.32 & 0.34 & 0.20 \\
\hline & Coscinodisceae & Melosira & 1.64 & 4.85 & 4.10 & 2.67 \\
\hline & Diatomophyceae & Asterionella & - & - & - & 0.06 \\
\hline & Nitzschiaceae & Nitzschia & - & - & 0.04 & 0.01 \\
\hline & Coscinodisceae & Cyclotella & - & - & - & 0.03 \\
\hline \multirow[t]{3}{*}{ Protozoans } & Chilodonellideae & Chilodonella & - & - & - & 0.03 \\
\hline & Chrysophyceae & Uroglena & - & - & 0.05 & 0.08 \\
\hline & Volvocaceae & Eudorina & 12.97 & 4.09 & 13.02 & 6.93 \\
\hline \multirow[t]{5}{*}{ Rotatoria } & Euchlanideae & Euchlanis & - & - & - & 0.04 \\
\hline & Euchlanideae & Colurella & 0.28 & 0.12 & 1.04 & 1.59 \\
\hline & Gastropodideae & Chromogaster & 0.50 & 0.10 & - & 0.06 \\
\hline & Philodinideae & Rotaria & - & - & 0.15 & 0.005 \\
\hline & Trichocercideae & Trichocerca & - & - & 0.11 & 0.22 \\
\hline \multirow[t]{3}{*}{ Copepoda } & Cyclopideae & Tropocyclops & - & - & 0.08 & 0.15 \\
\hline & Diaptomideae & Arctodiaptomes & - & - & - & 0.007 \\
\hline & Diaptomideae & Diaptomus & - & - & 0.02 & 0.01 \\
\hline Cladocera & Cladocera & Camptocercus & 4.24 & - & - & 0.01 \\
\hline \multirow[t]{2}{*}{ Crustaceans } & Chirocephalidae & Eubranchipus & - & - & 0.22 & 0.13 \\
\hline & Crustacean & Metazoe larvae & - & - & - & 0.02 \\
\hline Insect parts & & & 0.28 & 2.86 & 1.16 & 0.54 \\
\hline Detritus & & & 16.24 & 12.27 & 12.89 & 12.19 \\
\hline Sand grains & & & 6.86 & 9.67 & 17.60 & 24.85 \\
\hline $\begin{array}{l}\text { Unidentified } \\
\text { preys }\end{array}$ & & & 1.24 & 3.61 & 0.71 & 0.33 \\
\hline
\end{tabular}




\section{$\square$ Wet $\square$ Flood $\square$ Dry}

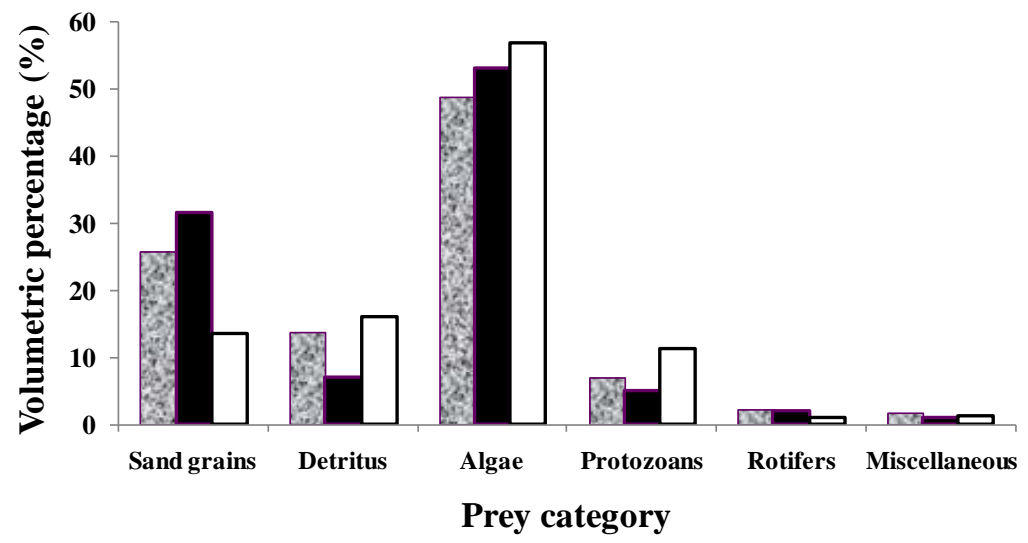

Figure 3. Seasonal trends of the volumetric percentage (\%) of the foods resources ingested by Sarotherodon galilaeus $(\mathrm{n}=1189)$ from the artificial lake of Ahozon (South-Benin).

consumption of some algae such as Synechocystis (Chroococcaceae), Microcystis (Chroococcaceae) and Closterium (Desmidiaceae) increased with the sizes of $S$. galilaeus. This trend was shown by the positive slopes $(b)$ ranging between 0.033 and 0.164 and the correlation coefficient varying from $0.79-0.99$ recorded from the linear regression equations between the fish sizes and the volumetric proportion of these food resources.

\subsection{Ecomorphological Correlates}

The ecomorphological trends of the trophic structure of S. galilaeus has been analyzed by plotting the volumetric proportion of each prey ingested (detritus, sand particles, algae etc.) against total length (TL) and gut length (GL). The linear regression equations indicated that TL and GL were positively (slope $b_{T L}=0.241 ; b_{G L}=0.280$ ) correlated with the volumetric proportion of sand particles with significant $(p \leq 0.05)$ correlation coefficients $r=$ 0.99 and $r=0.87$, respectively, indicating that the consumption of sand particles increased with TL and GL (Table 6, Table 7). The same trends were recorded for dominant algae of high occurrence and high volumetric proportions such as Synechocystis (Chroococcaceae), Microcystis (Chroococcaceae) (Table 6, Table 7). In addition, ecomorphological relationships were explored by plotting GL against body weight (W) and standard length (SL). To lessen skew in the dataset, logarithmic transformations were applied to GL, W and SL. Also, the ratio of SL to GL (GL/SL) was computed as a measure of relative gut length and compared to reference values. The linear regression equations obtained were as follows:

$$
\begin{aligned}
& \operatorname{LOG}(\mathrm{GL})=0.560 * \operatorname{LOG}(\mathrm{W})+1.011, R^{2}=0.89, N=1189 \quad \text { (Figure 4) } \\
& \mathrm{LOG}(\mathrm{GL})=1.613 * \operatorname{LOG}(\mathrm{SL})+0.312, R^{2}=0.87, N=1189 \quad \text { (Figure 5) }
\end{aligned}
$$

The slopes, $b=0.560$ and $b=1.613$ of both equations were positive with significant $(p \leq 0.05)$ correlation coefficients $r=0.94$ and $r=0.93$, respectively. The ratio of GL/SL ranged between 1 (30 mm SL) and 13.85 (68 $\mathrm{mm} \mathrm{SL}$ ) with a mean of $6.72 \pm 2.23$.

\section{Discussions}

\subsection{Food and Feeding Patterns}

The success of fisheries and aquaculture valorizations of a species in a man-made lake require knowledge on feeding ecology in order to evaluate the food resource exploitation and utilization, and the establishment of the fishes in this artificial habitat [32] [33]. The present study indicated that S. galilaeus consumed about seventy (70) food resources composed of a variety of benthic and pelagic prey items dominated by algae (52.88\%) constituated of blue-green algae, green algae, desmids and diatoms, sand particles (23.95\%), detritus (12.27\%) and protozoans (8.69\%). Though consuming about 52 genera of algae, only ten (10) of them, Microcystis (Chroo- 


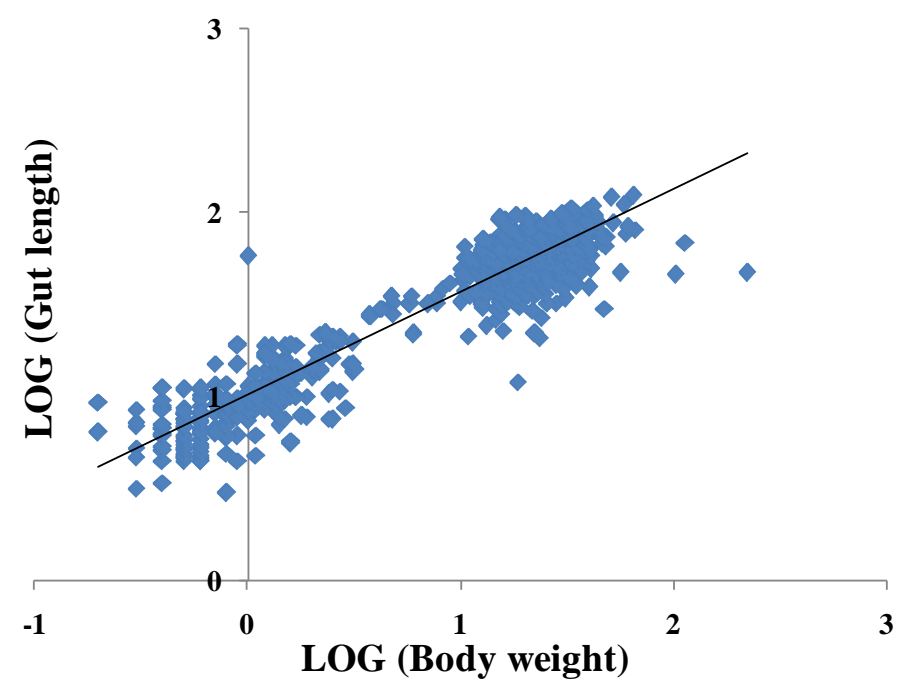

Figure 4. Relationship between Log (gut length) and Log (body weight) of Sarotherodon galilaeus $(\mathrm{N}=1189$ ) from the artificial lake of Ahozon (South-Benin). Regression equation and coefficient of determination were as follows: $\log (\mathrm{GL})=0.560 * \log$ (W) $+1.011, \mathrm{R}^{2}=0.89$.

Table 6. Linear regression between the volumetric percentages (\%) of food resources consumed and total length (TL) of Sarotherodon galilaeus $(\mathrm{N}=1189)$ from the artificial lake of Ahozon (South-Benin).

\begin{tabular}{cccccc}
\hline Regressions factors & $\begin{array}{c}\text { No. of fish size } \\
\text { categories }\end{array}$ & Slope $(\boldsymbol{b})$ & $\begin{array}{c}\text { Determination } \\
\text { coefficient }\end{array}$ & Correlation coefficient & Intercept \\
\hline Sand particles & 4 & 0.241 & 0.96 & 0.99 & 1.787 \\
Synechocystis (Chroococcaceae) & 4 & 0.041 & 0.97 & 0.99 & 0.337 \\
Microcystis (Chroococcaceae) & 4 & 0.164 & 0.88 & 0.94 & 2.337 \\
Closterium (Desmidiaceae) & 4 & 0.033 & 0.62 & 0.79 & 3.604 \\
\hline
\end{tabular}

Table 7. Linear regression between the volumetric percentages (\%) of food resources consumed and gut length (GL) of Sarotherodon galilaeus $(\mathrm{N}=1189)$ from the artificial lake of Ahozon (South-Benin).

\begin{tabular}{cccccc}
\hline Regressions factors & $\begin{array}{c}\text { No. of fish size } \\
\text { categories }\end{array}$ & Slope (b) & $\begin{array}{c}\text { Determination } \\
\text { coefficient }\end{array}$ & Correlation coefficient & Intercept \\
\hline Sand particles & 4 & 0.280 & 0.75 & 0.87 & 8.407 \\
Synechocystis (Chroococcaceae) & 4 & 0.040 & 0.54 & 0.72 & 1.634 \\
Microcystis (Chroococcaceae) & 4 & 0.170 & 0.54 & 0.74 & 2.337 \\
Closterium (Desmidiaceae) & 4 & 0.0174 & 0.063 & 0.25 & 5.077 \\
\hline
\end{tabular}

coccaceae), Scenedesmus (Scenedesmaceae), Closterium (Desmidiaceae), Synechocystis (Chroococcaceae), Coelosphaerium (Chroococcaceae), Botryoccocus (Dictyosphaeriacae), Navicula (Naviculaceae), Melosira (Coscinodisceae), Pinnularia (Naviculaceae) and Nostoc (Nostocaceae) were the most abundant and gave an aggregated volumetric proportion of $44.93 \%$. This “alguivore”-like trophic specialization of S. galilaeus probably results from anatomical structures, mainly the presence of numerous gill rakers (20 - 27), which facilitated the filtering of numerous algae species [34].

The broad spectrum of the food items found in the stomachs of $S$. galilaeus is comparable or similar to what have been reported from numerous studies on tilapine cichlids. Greenwood [35] recorded a mixture of phytoplanktons and zooplanktons in the gut of S. galilaeus. According to Adebisi [36], S. galilaeus fed on desmids, diatoms, blue-green algae and benthic protozoans in the Upper Ogun River. As reported by Akintunde \& Imevbore [37], phytoplankton was the main food item as being present in the diet of S. galilaeus from Kaindji Lake. 


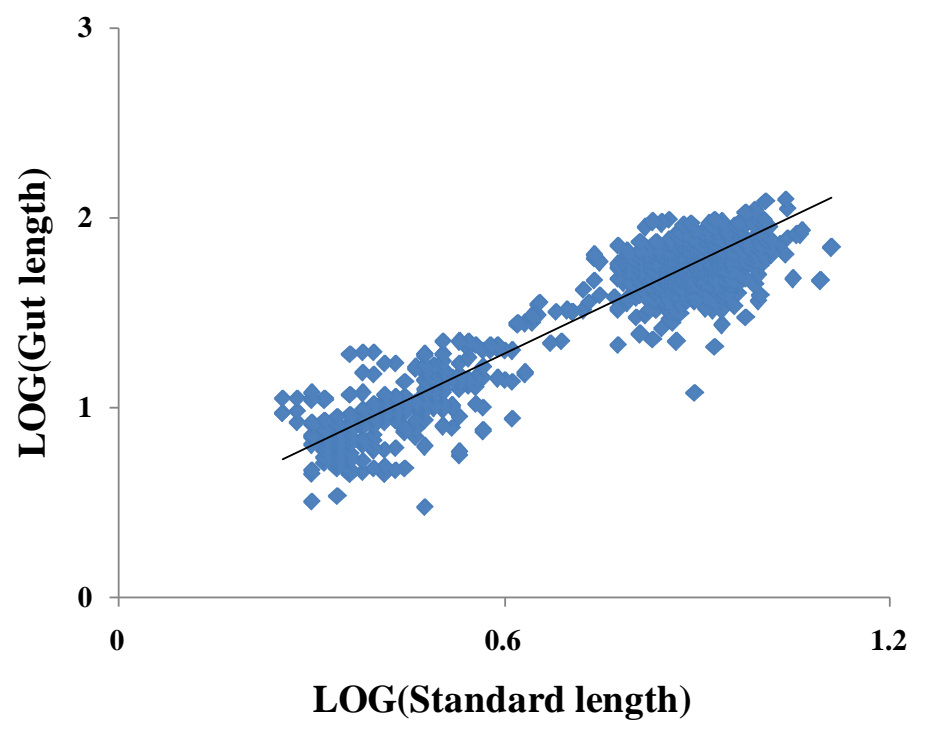

\begin{abstract}
Figure 5. Relationship between Log (gut length) and Log (standard length) of Sarotherodon galilaeus $(\mathrm{N}=1189)$ from the artificial lake of Ahozon (South-Benin). Regression equation and coefficient of determination were as follows: Log (GL) = $1.613 * \log (\mathrm{SL})+0.312, \mathrm{R}^{2}=0.87$.
\end{abstract}

Fish [38] [39] and Fagade [40] [41] reported that many tilapine species foraged mainly on diatoms. In the International Institute of Tropical Agriculture (IITA) lake of Ibadan, algae dominated the stomach content of S. galilaeus with a proportional consumption of 70\% [42]. Arame [43] reported the same trends for two other cichlids, Sarotherodon melanotheron and Oreochromis niloticus which consumed respectively, about 90 and 56 species of phytoplanktons, aggregating dietary volumetric proportions of about $86.88 \%$ and $62.74 \%$, respectively. Though not tilapine species, the bonytongue Heterotis niloticus, an omnivore, because of the presence of numerous gill rakers (42 - 94 on the first branchial arch) during its whole life, ingested various algae taxa such as diatoms (Raphoneis, Pleurosigma, Synedra, Nitzschia, Gomphonema, Melosira, Tabellaria, Asterinella, Navicula), Polycistis, Protococcus, Phormidium, Coelosphaerium, Nostoc, Oscillatoria, Merismopodia), green algae (Rhizodonium, Botyoccocus, Ulothrix sp., Richterella, Spirogyra, Coelastrum) and desmids (Gonatozygon, Closterium) [34]. Nevertheless, in the current study, the $23.95 \%$ of sand particles and the $12.27 \%$ of detritus recorded in the diet of $S$. galilaeus reflected both the benthic-like and detritivore-like foraging behavior of this species. The relatively high proportion of sand particles in the diet suggests that, probably, S. galilaeus ingested sand as normal diet components. Also, sand grains may help in the maceration of food materials in the pyloric stomach as observed in feeding ecology studies of mullets [8].

Of the 70 food resources ingested by $S$. galilaeus, ten (10) consistently occurred in a relatively high number of stomachs ranging between 262 (22.04\%) stomachs containing Synechocystis (Chroococcaceae) and 860 (72.33\%) stomachs containing sand particles. When considering the aggregated algae, 1025 (86.21\%) stomachs contained phytoplankton species which appeared to be the major food items occurring in most stomachs. In the IITA lake of Ibadan, Fagade [42] reported similar trends of algae occurrence ranging between 193 (18.71\%) for a filamentous algae (Spirogyra) to 750 (98.81\%) for diatoms with blue-green algae (Anabaena, Oscillatoria) occurring in 709 (93.41\%) stomachs [34]. In Lake Toho (South-Benin), Arame [43] reported some percentage occurrences of $60.79 \%$ for Melosira (Coscinodisceae) and $58.48 \%$ for Scenedesmus (Scenedesmaceae) in the dietary of the tilapine cichlid, Sarotherodon melanotheron. Also, in the same lake, Zygnema (green algae) and Melosira (Coscinodisceae) occurred in 59.19\% and 44.29\% stomachs of Oreochromis niloticus, respectively [43].

The study revealed insignificant $(p>0.05)$ seasonal variations of empty stomach, that is, the number of empty stomachs recorded was not associated with seasons. In contrast, the results showed ontogenetic variations of empty stomachs which significantly $(p \leq 0.05)$ varied with the life stage categories of $S$. galilaeus. Indeed, lower size classes (small juveniles) exhibited higher percentage of empty stomachs (28.57\% - 83.33\%) compared to adults exhibiting lower empty stomachs varying between $0.40 \%$ and $11.76 \%$. The higher percentage of empty 
stomach recorded in small juveniles was probably due to limited access to the food resources coupled with the undeveloped digestive tractus [34].

In Lake Ahozon, S. galilaeus had a broader diet breadth resulting from the numerous food resources (70 prey items) consumed, and ranging between $\mathrm{DB}=5.5$ for small juveniles and $\mathrm{DB}=7.29$ for subadults (mean: $6.39 \pm$ 0.87). In general, diet breadths tended to increase with the size of $S$. galilaeus, indicating that this species ingested a broader range of prey items as it grew [9]. However, the lack of seasonal variations in the diet breadth was probably due to the fact that Lake Ahozon was isolated and lacked connection with other water bodies such as coastal lagoons (brackish waters) or running waters (rivers, streams) which could cause intrusion of alien food resources. Nevertheless, the relatively low diet breadth (mean: $5.40 \pm 1.41$ ) recorded during the flooding season was probably due to the reduced planktonic bloom caused by high water turbidity that inhibited or limited photosynthetis. Compared to other tilapine cichlids, the diet breadth (mean: $5.40 \pm 1.41$ ) obtained for $S$. galilaeus in the man-made lake of Ahozon was lower than that $(8.01 \pm 3.30)$ recorded for Sarotherodon melanotheron from Lake Toho, a Southern Benin floodplain lake. Probably, this difference was the result of differential food availability in both lakes. Lake Toho is an ancient natural floodplain lake connected to Mono River and should dwell higher food resources than Lake Ahozon, a younger man-made water body isolated from the other inland waters. In addition, the difference in anatomical structures of both species could affect their foraging yields. For exemple, S. galilaeus shows 20 - 27 gill rakers on the first branchial arch compared to 27 - 30 gill rakers recorded for $S$. melanotheron [24].

The study consistently showed high diet similarities between size classes, indicated by high diet overlaps ranging between $\varnothing_{j k}=0.77$ and $\varnothing_{j k}=0.97$. Also, individuals with adjacent size classes tended to have higher diet overlaps than pairings of distant size classes (Table 3). These trends indicated ontogenetic diet shifts in S. galilaeus shown for exemple by the increase in sand particles consumptions as the fish grew [9].

In the artificial lake of Ahozon, proportional consumptions of most food resources, such as sand particles, combined algae, protozoans and rotifers ingested by S. galilaeus exhibited insignificant $(p>0.05)$ seasonal variations. Probably, these prey items may have been available all seasons (wet, flood, dry) so that $S$. galilaeus may have unlimited access and consumed them ad libitum according to their needs and food requirements. However, the proportional consumption of detritus showed significant $(p \leq 0.05)$ seasonal variations, but higher consumption (17.44\%) occurred in the dry season. Indeed, during the dry season, the lake's water should be less turbid and relatively calm, with bottom substrates more stable and more available for the fish, compared to the wet and flood seasons characterized by high water disturbance causing unstable bottom/substrates and high turbidities.

\subsection{Trophic Plasticity}

This investigation showed that $S$. galilaeus exhibited a wide diet breadth resulting from the broad spectrum of food consumed and composed of 18 genera of blue-green algae, 9 genera of green algae, 13 genera of desmids, 12 genera of diatoms, 3 genera of protozoans, 5 genera of rotifers, 3 genera of copepods, 1 genus of cladocera, 2 genera of crustacean, insect parts, detritus and sand particles. Although the proportional consumption of these food items were not equally represented in the diet, the wide choise of foods available to $S$. galilaeus suggests that when one prey was in reduced supply, the species could forage on another abundant and available prey of the man-made lake [42]. As reported by Bowen et al. and Adite et al. [9] [18] this food habit pattern is an indicator of trophic plasticity in S. galilaeus which may shift its feeding structure according to prey availability in the man-made lake of Ahozon. This trophic plasticity results from specialized anatomical structures, mainly the presence of numerous gill rakers, 20 - 27 on the first branchial arch, which facilitate the filtering of numerous algae species [9] [34].

\subsection{Ecomorphological Relationships and Food Habits}

In Lake Ahozon, the highly significant $(p \leq 0.05)$ positive correlation coefficients, $r=0.99$ and $r=0.87$, recorded respectively from both regression equations of $\log (\mathrm{TL})$ and $\log (\mathrm{GL})$ with the proportional consumption of detritus indicated that the consumption of detritus increased with the size and the development of the digestive tract of S. galilaeus [34]. Also, some relatively abundant and dominant algae such as Synechocystis (Chroococcaceae), Microcystis (Chroococcaceae) and at some extent, Closterium (Desmidiaceae) followed the same ecomophological pattern. According to Adite et al. [9], small fish individuals with less developed digestive system forage mostly on live food, and as the digestive tract becomes well-developed, they take advantage to other 
delicate resources such as detritus [34].

In the current study, the linear regression between $\log (\mathrm{W})$ and $\log (\mathrm{GL})$ gave a positive slope $b=0.560$. This value fails into Kramer \& Bryant (1995) omnivore slope range (0.4 - 0.68) supporting that $S$. galilaeus may be an omnivore. However, the slope $b=0.560$ also is close to Kramer \& Bryant [44] herbivore slope range (0.58 - 0.68) which aligns $S$. galilaeus with herbivore. Furthermore, in S. galilaeus, the ratio of SL to GL (GL/SL) ranged between 1 (30 mm SL) and 13.85 (68 mm SL) with a mean of $6.72 \pm 2.23$ which also is close to Paugy's [45] African detritivorous fishes ratio (mean $=7.2$ ). In Lake Ahozon, the dominant food resources consumed by S. galilaeus were sand particles (23.95\%), detritus (12.27\%) and algae (52.88\%), occurred respectively in 860 (72.23\%) stomachs, 826 (69.47\%) stomachs and 1025 (86.21\%) stomachs. Consequently, the slope $b=0.560$ obtained from the linear regression $\log (\mathrm{W})$ - Log $(\mathrm{GL})$ and the mean ratio GL/SL $=6.72 \pm 2.23$ support our findings that $S$. galilaeus exhibited detritivorous, herbivorous (alguivorous) and omnivorous food habits because of the sand particles \& detritus consumed (36.22\%), the proportional consumption of algae (52.88\%) and its balanced diet that included about $10.09 \%$ of animal materials.

\subsection{Implications for Species Establishment and Valorization}

The current investigation on the feeding ecology of $S$. galilaeus revealed that this naturally-colonized tilapine cichlid is well-established in the artificial lake of Ahozon. Indeed, the study consistently showed that S. galilaeus exploit and utilize in Lake Ahozon, a combination of plant and animal resources as source of foods. Though dominated by algae (52.88\%) composed of 28 famillies and 52 genera and detritus \& sand particles (36.22\%), the diet also included about $10.09 \%$ of animal organisms composed of protozoans, microcrustacea (rotifers, copepods, cladocera) and insect parts. The ability of S. galilaeus to exploit and to utilize this wide variety of available food resources to satisfy its nutrional needs accounted for the prominence, the abundance and the perfect establishment of the species in the man-made lake of Ahozon. The physical structure of the lake allowed the availability of aquatic vegetation habitat at the shallower lake margin, considered not only as a potential source of food resources, but also as potential spawning ground for most fishes including S. galilaeus. Hence, the availability of food would insure rapid growth leading to early maturation, and the presence of suitable reproduction grounds would lead to a greater recruitment and high propagation of the species in the man-made lake of Ahozon. As results, the broad spectrum of food items consumed, the high diet breadth, the active reproduction of the species, the allometric/isometric growths and the greater prominence of the species were some indicators of the successful establishment of $S$. galilaeus in the man-made lake of Ahozon. In addition, the high ecological niche is an advantage for the aquacultural valorization of $S$. galilaeus, and particularly in extensive aquaculture systems where habitat conditions are close to those of natural lakes. Successful and sustainable fisheries valorization/management of the species require 1) the protection of its habitats, mainly spawning and foraging grounds, 2) the introduction of predators to control the population of the species, 3) the prevention of domestic wastes dumping 4) the planned harvest of the fish stock, 5) the fertilization of the lake by installing a park of branches in the lake, and 6) the protection of the lake margin to avoid erosion. Especially to enhance aquaculture valorization, some medium-environments such as "net enclosures" and "floating cages" could be introduced in the lake for intensive rearing of S. galilaeus and other fish species such Oreochromis niloticus, Clarias gariepinus and Chrysichthys nigrodigitatus.

\section{Conclusion}

The current study gives quantitative and qualitative information on the trophic ecology of the freshwater tilapine cichlid Sarotherodon galilaeus and its establishment in the man-made lake of Ahozon. The results consistently showed that $S$. galilaeus exploited and utilized a broad spectrum of food resources in the artificial lake of Ahozon. Main prey items included blue-green algae, green algae, desmids, diatoms, sand particles, detritus, protozoans and microcrustacean that conferred to the species, an herbivorous (alguivorous), detritivorous and omnivorous food's habits. The broad spectrum of food items consumed and the high diet breadth recorded leading to allometric/isometric growth, the early maturation, the active breeding and the high propagation of the species in the lake, are some indicators of the successful establishment of S. galilaeus in the man-made lake of Ahozon. An integrated management scheme of Lake Ahozon must include the periodic ecological monitoring of the lake, the protection of the reproduction and foraging grounds and the valorization of S. galilaeus in fisheries and aquaculture along with a conservation plan. 


\section{Acknowledgements}

Logistic and financial assistance were provided by the "Laboratoire d'Ecologie et de Management des Ecosystèmes Aquatiques, Département de Zoologie, Faculté des Sciences et techniques, Université d’Abomey-Calavi”. We express our gratitude to Mr Doukpo Célestin, the owner of the artificial lake to allow us to conduct this investigation on both man-made lakes. We are also grateful to Mr Houessinon Geoffroy, Houndjetin Louis and Djihouessi Bernold for their assistance in fish sampling and laboratory works. We thank the numerous reviewers for their thorough peer-review of this manuscript.

\section{References}

[1] Van Thielen, R., Hounkpe, C., Agon, G. and Dagba, L. (1987) Guide de determination des poissons et crustacés des lagunes et lacs du Bas Bénin. GTZ \& Direction des Pêche, Cotonou, Benin.

[2] Adite, A. and Van Thielen, R. (1995) Ecology and Fish Catches in the Natural Lakes of Benin, West Africa. Environmental Biology of Fishes, 43, 381-391. http://dx.doi.org/10.1007/BF00001173

[3] Djihouessi, M.B. (2015) Ecologie et valorisation piscicole des lacs artificiels du Sud-Bénin (Bénin, Afrique de l’Ouest). Master's Thesis, FAST, Université d’Abomey-Calavi, Bénin.

[4] Gbaguidi, G.A.M.H., Adite, A. and Sossoukpe, E. (2016) Ecology and Fish Biodiversity of Some Artificial Lakes of Southern Benin (West Africa): Implications for Fisheries Management and Aquaculture Valorization. Journal of Environmental Protection, In Press. http://dx.doi.org/10.4236/jep.2016.76079

[5] Jimoh, A.A., Clarke, E.O., Whenu, O.O. and Adeoye, H.B. (2011) Foods and Feeding Habits of the African River Prawn (Macrobrachim vollenhovenii, Herklots, 1857) in the Epe Lagoon, Southwest Nigeria. International Journal of Fisheries and Aquaculture, 3, 10-15.

[6] Nunoo, F.K.E., Sossoukpe, E., Adite, A. and Fiogbe, D.E. (2013) Foods Habits of Two Species of Pseudotolithus (Scianidae) off (West Africa) near Shore Waters and Implications for Management. International Journal of Fisheries and Aquaculture, 5, 142-151.

[7] Newell, R.I.E. and Jordan, S.J. (1983) Preferential Ingestion of Organic Material by the American Oyster Crassostrea virginica. Marine Ecological Progress Series, 13, 47-53. http://dx.doi.org/10.3354/meps013047

[8] Amisah, S. and Agbo, N.W. (2008) An Investigation into the Food and Feeding Ecology of a Potential Aquaculture Candidate, Sarotherodon galilaeus multifasciatus in a Meteoritic Crater Lake in Ghana. Journal of Applied Sciences and Environmental Management, 12, 15-18.

[9] Adite, A., Winemiller, K.O. and Fiogbe, D.E. (2005) Ontogenetic, Seasonal, and Spatial Variation in the Diet of Heterotis niloticus (Osteoglossiformes; Osteoglossidae) in the Sô River-Lac Hlan System, Benin, West Africa. Environmental Biology of Fishes, 3, 367-378. http://dx.doi.org/10.1007/s10641-004-5563-9

[10] Lauzanne, L. (1976) Régimes alimentaires et relations trophiques des poissons du lac Tchad.Cahiers ORSTOM, Sér.Hydrobiologie, 10, 267-310.

[11] Hickley, P. and Bailey, R.G. (1987) Foods and Feeding Relationships of the FSH in the Sudd Swamps. Journal of Fish Biology, 30, 147-159. http://dx.doi.org/10.1111/j.1095-8649.1987.tb05741.x

[12] Fagade, S.O. and Olaniyan, C.I.O. (1973) The Foods and Feeding Interrelationships of the Fishes in the Lagos Lagoon. Journal of Fish Biology, 5, 205-225. http://dx.doi.org/10.1111/j.1095-8649.1973.tb04449.x

[13] Winemiller, O.K. (1990) Spatial and Temporal Variation in Tropical Fish Trophic Network. Ecological Monographs, 60, 331-367. http://dx.doi.org/10.2307/1943061

[14] Winemiller, K.O. (1989) Ontogenetic Diet Shifts and Resource Partitioning among Piscivorous Fishes in the Venezuelan Llanos. Environmental Biology of Fishes, 26, 177-199. http://dx.doi.org/10.1007/BF00004815

[15] Steingrimsson, S.O. and Gislason, G.M. (2002) Body Size, Diet and Growth of Landlocked Brown Trout, Salmon trutta, in the Subarctic River Laxa, North-East Iceland. Environmental Biology of Fishes, 63, 417-426. http://dx.doi.org/10.1023/A:1014976612970

[16] Koen Alonso, M., Crespo, E.A., Garcia, N.A., Pedraza, S.N., Mariotti, P.A. and Mora, N.J. (2002) Fishery and Ontogenetic Driven Changes in the Diets of the Spiny Dogfish, Squalus acanthias, in Patagonian Waters, Argentina. Environmental Biology of Fishes, 63, 193-202. http://dx.doi.org/10.1023/A:1014229432375

[17] Barbarino Duque, A. and Winemiller, K.O. (2003) Dietary Segregation among Large Catfishes of the Apure and Arauca Rivers, Venezuela. Journal of Fish Biology, 63, 410-427. http://dx.doi.org/10.1046/j.1095-8649.2003.00163.x

[18] Bowen, S.H. and Allanson, B.R. (1982) Behavioral and Trophic Plasticity of Juvenile Tilapia mossambica in Utilization of the Unstable Littoral Habitat. Environmental Biology of Fishes, 7, 354-362.

http://dx.doi.org/10.1007/BF00005570 
[19] Garcia-Berthou, E. (1999) Food of Introduced Mosquitofish: Ontogenetic Diet Shift and Prey Selection. Journal of Fish Biology, 55, 135-147. http://dx.doi.org/10.1111/j.1095-8649.1999.tb00663.x

[20] Bowen, S.H. (1983) Detritivory in the Neotropical Fish Communities. Environmental Biology of Fishes, 9, $137-144$. http://dx.doi.org/10.1007/BF00690858

[21] Garcia-Berthou, E. and Moreno-Amich, R. (2000) Food of Introduced Pumpkinseed Sunfish: Ontogenetic Diet Shift and Seasonal Variation. Journal of Fish Biology, 57, 29-40. http://dx.doi.org/10.1111/j.1095-8649.2000.tb00773.x

[22] Adite, A. and Winemiller, K.O. (1997) Trophic Ecology and Ecomorphology of Fish Assemblages in Coastal Lakes of Benin, West Africa. Ecoscience, 4, 6-23.

[23] ASCENA (2003) Données sur la pluviométrie des années 2002 et 2003. Agence Pour la Sécurité de la Navigation Aérienne, Service de la Méréorologie Nationale Cotonou.

[24] Leveque, C., Paugy, D. and Teugels, G.G. (1990) Faunes des poissons d'eaux douces et saumâtres de l'Afrique de l'Ouest. Tome 1, Editions ORSTOM/MDRAC, Paris, 384.

[25] Lowe McConnell, R.H. (1975) Fish Communities in the Tropical Freshwaters. Longman, London, 337.

[26] Lowe McConnell, R.H. (1987) Ecological Studies in the in Tropical Fish Communities. Cambridge University Press, Cambridge, 382 p. http://dx.doi.org/10.1017/CBO9780511721892

[27] Moreau, J. (1982) Exposé synoptique des données biologiques sur Heterotis niloticus (Cuvier, 1929). Food and Agriculture Organization Synopsis de Pêches, 131, 1-45.

[28] Needham, G.J. and Needham, P.R. (1962) A Guide to the Study of Fresh-Water Biology. Holden Day, San Francisco.

[29] Morgan, G.A., Grieggo, O.V. and Gloeckner, G.W. (2001) SPSS for Windows: An Introduction to Use and Interpretation in Research. Lawrence Erlbaum Associates Publishers, Mahwah.

[30] Simpson, E.H. (1949) Measurement of Diversity. Nature, 163, 688. http://dx.doi.org/10.1038/163688a0

[31] Pianka, E.R. (1994) Evolutionary Ecology. 5th Edition, Harper Collins College Publishers, New York.

[32] Winemiller, K.O. and Kelso-Winemiller, L.C. (2003) Food Habits of Tilapiine Cichlids of the Upper Zambezi River and Floodplains during the Descending Phase of the Hydrological Cycle. Journal of Fish Biology, 63, 120-128. http://dx.doi.org/10.1046/j.1095-8649.2003.00134.x

[33] Welcomme, R.L. (1979) Fisheries Ecology of Floodplains Rivers. Longman, New York, 317 p.

[34] Adite, A. (2007) Ecologie de Heterotis niloticus (Osteoglossiformes: Osteoglossidae) du Système fluvio-lacustre rivière Sô-lac Hlan (Sud-Bénin): Conservation et Intérêt pour l'aquaculture. Ph.D. Dissertation, Faculté des Scienes et Techniques, Université d’Abomey-Calavi, Abomey-Calavi.

[35] Greenwood, P.H. (1953) Feeding Mechanism of the Cichlid Fish Tilapia esculenta Graham. Nature, 172, $207-208$. http://dx.doi.org/10.1038/172207c0

[36] Adebissi, A.A. (1978) Study on the Ecology, Growth and Reproduction of the Fishes of Upper Ogun River, Nigeria. Ph.D. Dissertation, University of Ibadan, Ibadan.

[37] Kintunde, E.A. and Imevbore, A.M.A. (1979) Aspects of the Biology of Cichlids Fishes of Lake Kainji with Special Reference to Sarotherodon galilaeus. Niger Journal of Natural Sciences, 1, 35-39.

[38] Fish, G.R. (1951) Digestion in Tilapia esculenta. Nature, 167, 900-901. http://dx.doi.org/10.1038/167900a0

[39] Fish, G.R. (1955) The Food of Tilapia in the East Africa. The Uganda Journal, 19, 85-89.

[40] Fagade, S.O. (1971) The Foods and Feeding Habits of Tilapia Species from the Lagos lagoons. Journal of Fish Biology, 3, 151-156. http://dx.doi.org/10.1111/j.1095-8649.1971.tb03659.x

[41] Fagade, S.O. (1978) On the Biology of Tilapia guineensis (Dumel) from the Lekki Lagoon, Lagos State, Nigeria. Niger Journal of Natural Sciences, 12, 73-87.

[42] Fagade, S.O. (1982) The Foods and Feeding Habits of Sarotherodon galilaeus from a Small Lake. Archiv für Hydrobiologie, 93, 256-263.

[43] Arame, H. (2012) Ecologie trophique comparée de Oreochromis niloticus (Perciforme: Cichlidae) introduit dans le lac Toho (Sud-Bénin) et de Sarotherodon melanotheron (Perciforme: Cichlidae): Implications pour la conservation de l’ichtyofaune du Lac Toho. Master’s Thesis, Faculté des Scienes et Techniques, Université d’Abomey-Calavi, Abomey-Calavi.

[44] Kramer, D.L. (1995) The Intestine Length in the Fish of a Tropical Stream: Ontogenetic Allometry. Environmental Biology of Fishes, 42, 115-125. http://dx.doi.org/10.1007/BF00001990

[45] Paugy, D. (1994) Ecologie des poisons tropicaux d'un cours d'eau temporaire (Baoulé, haut basin du Senegal au Mali): Adaptation au milieu et plasticité du régime alimentaire. Revue d'Hydrobiologie Tropicale, 27, 157-172. 